\title{
Utilizing Genetic Variation to Predict and Extend Long-Term Kidney Transplant Function
}

Dr Matthew J. Simmonds

Oxford Centre for Diabetes, Endocrinology and Metabolism (OCDEM), University of Oxford, Churchill Hospital, Headington, Oxford, OX3 7LE

Funding: MJS would like to thank the European Foundation for the Diabetes Research and Wellness Foundation (DRWF) Non-Clinical Fellowship scheme for providing fellowship funding during the course of writing this review.

Corresponding author and to whom reprints requests should be addressed:

Dr Matthew Simmonds, Oxford Centre for Diabetes, Endocrinology and Metabolism, University of Oxford, Churchill Hospital, Headington, Oxford OX3 7LE, UK

Telephone: +441865857289

Fax: +44 186585729

E-mail: matthew.simmonds@ocdem.ox.ac.uk 


\section{FOOTNOTES}

Dr Matthew Simmonds, researched and wrote this Overview. Dr Simmonds has no conflicts of interest to declare. 


\section{ABBREVIATIONS}

ABCB1 = ATP-binding cassette sub-family B member 1

APOL1 = Apolipoprotein L1

AUC $=$ Area Under the Curve

BMI = Body Mass Index

Cav-1 = caveolin-1

Cav-2 $=$ caveolin-2

Cnb1 $=$ calcinerin phosphatase regulators subunit

$\mathrm{CNV}=$ copy number variation

$\mathrm{CRM}=$ common rejection model

CYP3A = cytochrome P450 3A

FSGS $=$ focal segmental glomerulosclerosis

GWAS $=$ genome wide association study

$\mathrm{HDL}=$ High-density lipoprotein

HIVAN $=$ HIV associated nephropathy (HIVAN)

HLA $=$ Human Leukocyte Antigen

$\mathrm{HR}=$ hazard ratio

$\mathrm{KIR}=$ killer immunoglobulin-like receptors

mRNA $=$ messenger RNA

$\mathrm{NF}-\kappa \mathrm{B}=$ nuclear factor kappa-light-chain-enhancer of activated $\mathrm{B}$ cells

NFAT $=$ nuclear factor of activated T-cells

NFSE $=$ nifedipine-specific element

$\mathrm{NK}=$ natural killer

NODAT $=$ new onset of diabetes after transplant

OPTN $=$ Organ Procurement and Transplantation Network

$\mathrm{PCR}=$ polymerase chain reaction

$\mathrm{SNP}=$ single nucleotide polymorphism

STAT1 $=$ Signal transducer and activator of transcription 1

$\mathrm{T} 1 \mathrm{D}=$ Type 1 diabetes 
$\mathrm{T} 2 \mathrm{D}=$ Type 2 diabetes

TGF- $\beta 1=$ Transforming growth factor beta 1

UNOS $=$ United Network for Organ Sharing

$\mathrm{XCI}=\mathrm{X}$ chromosome inactivation 


\section{ABSTRACT (250 out of 250 words maximum)}

Renal transplantation has transformed the life of patients with end-stage renal disease and other chronic kidney disorders by returning endogenous kidney function and enabling patients to cease dialysis. Several clinical indicators of graft outcome and long-term function have been established. Whilst rising creatinine levels and graft biopsy can be used to determine graft loss, identifying early predictors of graft function will not only improve our ability to predict longterm graft outcome but importantly provide a window of opportunity to therapeutically intervene to preserve graft function before graft failure has occurred. Since understanding the importance of matching genetic variation at the HLA region between donors and recipients and translating this into clinical practise to improve transplant outcome, much focus has been placed on trying to identify additional genetic predictors of transplant outcome/function. This review will focus on how candidate gene studies have identified variants within immunosuppression, immune response, fibrotic pathways and specific ethnic groups which correlate with graft outcome. We will also discuss the challenges faced by candidate gene studies, such as differences in donor and recipient selection criteria and use of small datasets, which have led to many genes failing to be consistently associated with transplant outcome. This review will also look at how recent advances in our understanding of and ability to screen the genome are starting to provide new insights into the mechanisms behind long-term graft loss and with it the opportunity to target these pathways therapeutically to ultimately increase graft lifespan and the associated benefits to patients. 


\section{OVERVIEW (6500 words including Abstract and Figure/Table legends)}

\section{Kidney Transplantation in Action}

Improvements in induction/immunosuppressant regimes, sharing of technical expertise between centres, establishment of organ allocation networks and increased numbers of transplant centres have enabled kidney transplantation to become a successful treatment for patients with end-stage renal failure. Establishment of the Organ Procurement and Transplantation Network (OPTN)/United Network for Organ Sharing (UNOS), Eurotransplant and others databases have lead the way in identifying donor and recipient features and measures of renal function which act as indicators of long-term transplant success including cold ischemia time, deceased vs living donor and $\operatorname{BMI}(1,2)$. Whilst donors and recipients are matched for clinical features shown to maximise transplant success, some immediate and early complications can occur after transplantation including haemorrhage, thrombosis, intraabdominal infection and acute rejection $(1,3)$. Many of these are treatable with surgery or changes in immunosuppressant/induction regimes, leading to $90-95 \%$ of cadaveric donor organs and $\sim 100 \%$ of living donor organs still functioning one year post transplant. Over time however kidney graft function declines, with $>50 \%$ of deceased donor transplanted kidneys failing within 10 years and $>50 \%$ of living related donor transplant kidneys failing within 17 18 years (4). Whilst kidney biopsy and creatinine levels can determine graft failure, usually this is after substantial graft damage has occurred.

Due to the importance of providing equity of access to kidney transplants across different ethnic and social-economical groups and with waiting lists outstripping organ supply, it is not always possible to match purely on the best clinical indicators of long-term graft survival. It is also important to bear in mind that whilst clinical features provide indicators of transplant 
survival and long-term function, they are not definitive predictors of transplant longevity. One key feature of transplantation is that the donor and recipient, except between identical twins, differ in their genetic makeup. Utilisation of HLA matching has enabled transplantation to become one of the first fields to translate genetic information into improved graft outcome (3). The use of genetic markers to predict disease outcome in common diseases has however been questioned as whilst genetic factors can predict disease outcome as well as clinical features, when added to well-established clinical predictors in common autoimmune and metabolic diseases they do not improve disease prediction $(5,6)$. In transplantation where we do not have good clinical predictors of long-term graft survival/function, identifying genetic predictors of graft dysfunction could provide a window of opportunity to intervene therapeutically to prevent organ loss early on extending the benefits to patients of having a functioning graft.

The next section of this review is going to focus on the role of HLA mismatching in transplant outcome and the use of candidate gene studies to search for additional genetic predictors of graft outcome including variants involved in immunosuppressant metabolism, immune response, fibrosis and factors that contribute to transplant loss in different ethnicities (see Figure 1).

\section{HLA Matching - The Original Genetic Predictor of Transplant Outcome}

HLA antibodies represent a significant risk factor for hyper-acute rejection and can contribute to chronic rejection $(3,7)$. The HLA region encodes numerous molecules involved in presentation of exogenous and endogenous antigens for recognition by the immune system (8). The immune system determines if antigens presented are self, triggering no response, or nonself, causing an immune response to be triggered. If the donor organ encodes different HLA 
molecules to those recognised by the recipient's immune system, when encountered by the immune system alloantibodies against the donor organ will be generated. Understanding that matching donors and recipients for $H L A-D R B 1, H L A-A$ and $H L A-B$ would lead to reduced alloantibody production and improved transplant outcome is a keystone of most clinical transplant protocols.

HLA typing was initially undertaken looking at broad level (first field) matching between donors and recipients, based on HLA categorisation due to overarching structural similarities. Whilst it was well established that zero HLA mismatches have the highest success rate, other non-matched HLA donor-recipient pairings also did well (7). Split HLA specificities (second field) can further sub-divide the broad level typing by assigning the exact amino acid content at each broad HLA type. Both broad and split HLA typing give all mismatches the same weighting but does not reflect how each molecule presents antigens or how antibodies bind. This led to development of the HLAMatchmaker algorithm which rather than viewing HLA molecules as whole molecules it views them as a series of short linear sequences (triplets) of polymorphic amino acid residues in antibody-accessible positions (9-11). HLAMatchmaker assumes strings of amino acid form epitopes against which antibodies are created and patients cannot make antibodies against epitopes expressed by their own HLA molecules $(12,13)$. Revision to the original HLAMatchmaker was undertaken to take into account the three dimensional structure of HLA molecules with triplets expanded to include eplets, derived of longer discontinuous sequences of amino acids which form part of a given epitope (13). This algorithm was particularly useful in interpreting sera antibody reactivity patterns against HLA panels in highly sensitized patients to determine donors with acceptable mismatches and has been incorporated into Eurotransplant's clinical protocol for highly sensitised patients, 
resulting in shorter waiting times for donor kidneys and graft survival rates comparable to those seen in non-sensitized patients (14-18).

There is debate, however, over whether using split HLA matching or HLAMatchmaker provides improvements over broad HLA matching in clinical practise. Kidney transplant outcome data reported to UNOS and Eurotransplant registries, suggested HLA matching of amino acid triplets improved graft survival compared to serologically define broad level HLA typing (19). However, it was suggested any benefit of triplet matching may be due to underlying differences in number of mismatched HLA specificities (20). The UK Transplant Registry evaluated serologically defined broad vs split typing and amino acid based HLA analysis (looking at number and physiochemical properties of amino acid mismatches) in 5247 adult recipients receiving deceased donor kidney transplants (21). Transplants with zero broad HLA mismatches showed a small significant improvement in graft survival compared to those with one $H L A-A$ or $H L A-B$ mismatch. HLA matching based on split HLA specificities, however, provided little additional discrimination in graft survival. Transplants with a single split $H L A-A$ or $H L A-B$ mismatch were assessed to determine the impact of a number of mismatched amino acids on graft survival and after adjusting for broad HLA specificities, a significant increase in graft failure was found for those with two or more amino acid mismatches $(\mathrm{P}=0.015)(21)$. Taken together, this suggests split HLA matching does not provide additional benefits over broad HLA mismatch but analysing amino acid mismatches has greater predictive value for transplant outcome over traditional broad level typing (21). This demonstrates how refining HLA matching is providing additional insights into the role of the HLA region in transplant outcome.

\section{Immunosuppressant Metabolism}


Immunosuppression is essential for graft accommodation and is achieved by use of induction regimes along with maintenance drugs throughout life. Calcineurin inhibitors, including cyclosporine and tacrolimus, are the main forms of immunosuppressant. Calcineurin is activated by calcium signalling, causing dephosphorylation of its substrates, including nuclear factor of activated T-cells (NFAT) complexes, which translocate to the nucleus and alter gene expression (22-24) (Figure 2). Inhibition of calcineurin and downstream NFAT proteins is key to inhibiting $\mathrm{T}$ cell activation. Initial drug dosing is based on body weight, with therapeutic drug monitoring (TDM) of whole blood concentrations undertaken to titrate levels $(25,26)$. Achieving a balance between under and over immunosuppression is key to enabling long-term graft accommodation whilst preventing immunosuppressant side effects including nephrotoxicity, new onset of diabetes after transplant (NODAT), hypertension, infection and malignancies $(3,27,28)$. Inter-individual genetic variation which alters/ablates expression of genes involved in drug metabolism pathways can impact on both drug titration in the short term and in the longer term potentially contributes to immunosuppressant side effects, suggesting that harnessing this variation could improve drug dosing (29).

Cyclosporine and tacrolimus are metabolic substrates of cytochrome P450 3A (CYP3A) enzymes, CYP3A4 and CYP3A5 $(30,31)$. CYP3A4 and CYP3A5 are expressed in the liver and small intestines, with only CYP3A5 expressed in kidneys $(32,33)$. Expression of $C Y P 3 A 5$ is controlled by presence of the $6986 \mathrm{~A}>\mathrm{G}$ (rs776746) SNP in intron 3. Whilst those with the CYP3A5 AA or AG genotype (also known as CYP3A5*1/*1 or CYP3A5*1/*3, respectively) express functional CYP3A5, CYP3A5 GG homozygous carriers (CYP3A5*3/*3) do not express functional CYP3A5. CYP3A5 non-expressers require less tacrolimus to reach target drug concentrations, compared to $C Y P 3 A 5$ expressers and whilst rejection occurred earlier in 
CYP3A5 expressors ( 7 days vs 14 days, $\mathrm{p}=0.005$ ), no difference in biopsy confirmed acute rejection was seen (34). A randomized controlled trial comparing tacrolimus dosing using CYP3A5 genotype vs standard dosing showed target tacrolimus concentrations were reached quicker within the genotype-based group, however there were no differences in clinical outcome between groups, suggesting clinical utility of $C Y P 3 A 5$ genotype may be limited to reducing initial drug overexposure (35).

Variation in both $C Y P 3 A 4$ and $A B C B 1$, encoding p-glycoprotein efflux pump transporter which transports drug metabolites out of the intestine, liver and kidneys, have also been extensively screened $(30,31)$. Unlike $C Y P 3 A 5$, no variants in $C Y P 3 A 4$ or $A B C B 1$ cause total loss of function. The CYP3A4 -392A-G SNP (rs2740754), present within nifedipine-specific element (NFSE) within the 5' promoter region, has been extensively studied. Functional analysis of the $-392 \mathrm{G}$ allele (also referred to as CYP3A4*1B) showed increased CYP3A4 transcriptional activity, although these results are controversial $(30,31)$. More recent investigation of the CYP3A4 15389C-T (rs35599367) SNP in intron 6, showed the TT or CT genotypes (also known as CYP3A4*22/*22 and CYP3A4*1/*22 genotypes, respectively) was associated with lower CYP3A4 mRNA and protein expression in the liver compared to the CC genotype $(\mathrm{CYP} 3 \mathrm{~A} 4 * 1 / * 1)$, and was proposed to impact on CYP3A4 function and in turn tacrolimus clearance (36-38). Renal transplant recipients carrying the CYP3A4*22 allele required 30\% less tacrolimus than those with the CYP3A4*1/*1 genotype (39). Interestingly, the CYP3A4*22 genotype was mainly found in CYP3A5 non-expressers. CYP3A5 non-expressers recipients with CYP3A $4 * 1 / * 22$ genotype required a further $30 \%$ less tacrolimus than $C Y P 3 A 5$ non-expresser recipients with the CYP $3 \mathrm{~A} 4 * 1 / * 1$ genotype (39), suggesting that implementing personalised drug dosing based on the individuals genetic drug metabolism profile should be incorporated into clinical protocols. 
Within $A B C B 1$ the 1236C-T SNP in exon 12 (rs1128503), 2677G-T/A SNP in exon 21 (rs2032582) and 3435C-T SNP in exon 26 (rs1045642) have been extensively studied (30, 31). The non-synonymous 2677 SNP results in a change at amino acid position 893 from an Alanine to a Serine or Threonine whereas the 1236 and 3455 SNPs are synonymous, causing no amino acid change. Whilst functional studies have revealed some evidence for the 3435 TT genotype in reducing p-glyocprotein expression and a role for 2677 and 1236 in altering p-glycoprotein expression, conflicting reports on their effect on p-glycoprotein expression make it difficult to draw conclusions on their role in immunosuppressant metabolism $(30,31)$. Screening of all common $A B C B 1$ variation in 811 Caucasian kidney donors and recipients showed that donor 3435 non-CC genotypes were associated with increased risk of long-term graft failure $(\mathrm{HR}=1.69 ; 95 \% \mathrm{CI}=1.20-2.40 ; \mathrm{P}=0.003)$. This result was validated in two independent cohorts, 675 donors from Belfast, $\mathrm{UK}(\mathrm{HR}=1.68 ; 95 \% \mathrm{CI}=1.21-2.32 ; \mathrm{P}=0.002)$, and 2985 donors from the Collaborative Transplant Study $(\mathrm{HR}=1.84 ; 95 \% \mathrm{CI}=1.08-3.13 ; \mathrm{P}=0.006)$, suggesting that variation in drug metabolism is likely to impact upon transplant outcome (40).

Whilst further work is required to realise drug dosing based on genetic variation, it could also play a role in predicting NODAT onset which occurs in $20 \%$ of patients on calcineurin inhibitors within the first six months after transplantation (41). Calcineurin not only controls T cell signalling but in normal adult beta cells leads to NFAT activation, which promotes expression of numerous genes critical for beta cell function, proliferation and mass $(42,43)$. Mice with a beta cell specific calcineurin phosphatase regulatory subunit, calcineurin b1 (Cnb1) deletion develop age-dependent diabetes characterised by decreased beta cell proliferation and mass, reduced pancreatic insulin content and hypoinsulinemia (42). Greater understanding of how variation in initial immunosuppressant dosing and metabolism could 
provide important insights into NODAT onset and have implications for pancreas transplant function in simultaneous pancreas-kidney transplants.

\section{Immune Response Genes}

The potential impact of immune system variation on rejection and long-term graft accommodation led to numerous immune genes being screened for a role in transplant outcome, with particular focus on screening other parts of the HLA region, complement, autoimmune genes and other immune response genes as detailed below:

\section{Additional HLA associations}

Due to the success of HLA matching in transplantation and the high density of immune response genes encoded within the HLA region, additional HLA genes have been screened including $T N F-\alpha$ (extensively reviewed in (44)). Presence of strong linkage disequilibrium across the region, where variants within different HLA genes are inherited together in a nonrandom manner (8), has hampered efforts to determine additional effects independent of HLA class I and class II matching, with work ongoing to tease these out.

HLA class I molecules not only present endogenous antigens for recognition by the immune system but are also involved in inhibition of natural killer (NK) cells. NK cells form part of the innate immune response against intracellular infections and tumour cells and secrete proinflammatory cytokines causing cell lysis. NK cell cytotoxic activity is regulated through a balance between activating and inhibitory receptors present on their surface known as killer immunoglobulin-like receptors (KIR) (45). Activating KIR recognise ligands expressed by 
cells undergoing stress and inhibitory KIR bind to HLA class I molecules (45-47). If donors express different HLA class I molecules to the recipient, this could affect NK cell inhibition, with recipient NK cell alloreactivity suggested to influence organ transplant outcome. Some preliminary evidence for a role of KIRs in renal transplant has been found (48), suggesting further investigation of genes associated with the HLA region is warranted.

\section{Complement}

The complement cascade is a set of soluble and cell-bound components triggered by immune complexes (classical pathway), mannose-binding lectin and ficolins receptors (leptin pathway) or direct binding of $\mathrm{C} 3 \mathrm{~b}$ to the activated surface (alternative pathway) in response to pathogens, autoantibodies, apoptosis or ischemic cells $(49,50)$. All three pathways lead to C3 activation, $\mathrm{C} 3 \mathrm{a}$ and $\mathrm{C} 5 \mathrm{a}$ release and formation of $\mathrm{C} 5 \mathrm{~b}-9$ membrane attack complex resulting in cell disruption and lysis. Complement mediated injury can lead to hyper-acute and acute antibody mediated rejection and also plays a potential role in ischemic-reperfusion injury and cell mediated rejection (49). The C4d component of the complement system has already been harnessed as a predictor of classical complement pathway activation and donor specific alloantibody production. Within the classical pathway, C3 production activates $\mathrm{C} 4$, causing cleavage of $\mathrm{C} 4 \mathrm{~b}$ from $\mathrm{C} 4 \mathrm{~d}(51)$. C4b is quickly degraded, whilst $\mathrm{C} 4 \mathrm{~d}$ remains attached to the cell membrane close to the site of antibody attachment providing a 'footprint' of antibodymediated tissue injury, with C4d staining incorporated into the BANFF grading scheme as a marker of acute humoral rejection (50-52). The obvious role of complement in organ rejection has made it a target for genetic studies. Analysis of $C 3$ in 622 kidney donor-recipient pairs for variants associated with fast $(\mathrm{F})$ or slow $(\mathrm{S}) \mathrm{C} 3$ production, demonstrated that $C 3 \mathrm{~S} / \mathrm{S}$ recipients with a $C 3 \mathrm{~F} / \mathrm{F}$ or $C 3 \mathrm{~F} / \mathrm{S}$ donor had better long-term outcomes than those with a donor with $C 3$ 
S/S genotype (53). These preliminary results suggest a potential opportunity to therapeutically target the complement pathways to improve transplant survival (49), with further genetic screening of a role for variation in the complement system warranted.

\section{Autoimmunity Variants}

Variation in key regulators of T cell activation and function, including CTLA-4, PTPN22 and foxp3, has been associated with numerous autoimmune diseases (54). Much work has been undertaken to look at autoimmune genes in transplant outcome, producing conflicting reports $(55,56)$. Even meta-analysis of studies up to 2013 looking at selected variants within CTLA4, $C D 86, C D 28$ and $P D C D 1$ for a role in acute rejection only showed association of $C D 28$ ivs 3 $+17 \mathrm{C}$ allele with acute renal rejection $(\mathrm{OR}=1.74 ; 95 \% \mathrm{CI}=1.11-2.75, \mathrm{P}=0.02)(55)$. However, this meta-analysis, like most other studies, only screened selected variants within these gene regions, suggesting that until further screening of these autoimmune genes in larger, more statistically powerful transplantation datasets is undertaken it is impossible to rule out a role for these variants.

\section{Cytokines and Other Immune Response Genes}

Cytokines are produced by macrophages, $\mathrm{T}$ cells and $\mathrm{B}$ cells and play a key role in initiating and regulating the immune response. This has made these genes obvious potential triggers of acute and long-term rejection in transplantation, and after the HLA region are the most studied genes for a role in transplantation. Over the years various cytokines and other immune response genes (see Table 1), have been investigated, however a lack of consistent association of these 
genes with transplant survival has cast doubt over their potential role (as reviewed in $(3,7,44$, $57,58))$

Incomplete screening of all common variation within these genes, combined with small datasets may, in part, explain the lack of consistent association (see Table 2). As the immune response is dynamic and varies significantly across the lifetime of the graft, this makes it inherently difficult to measure the impact of cytokines on transplant outcome. However, improvement in screening the genome and the use of larger datasets has enabled some evidence for a role of cytokines in transplant outcome to emerge. Meta-analysis of variants within transforming growth factor-beta 1 (TGF- $\beta 1)$, which is produced by all leukocytes and plays a key role in controlling inflammation $(59,60)$, from five different studies showed some evidence for association of a $T G F-\beta 1$ codon 10 polymorphism $(\mathrm{OR}=1.51,[95 \% \mathrm{CI}=1.03-2.22])$ with poor graft outcomes (57). Interestingly, GWAS screening for new susceptibility loci for diabetic nephrology in type 1 diabetics revealed genome wide significance for $A F F 3$, which play a role in TGF- $\beta 1$ induced fibrosis in renal epithelial cells, providing further evidence for $T G F-\beta 1$ pathways in renal dysfunction (61). This suggests that whilst currently the role of cytokines in transplant outcomes remain uncertain, without further work we cannot rule out a role for these variants in transplant survival.

\section{Fibrosis}

Fibrosis is a key hallmark of graft rejection and is caused by dysregulated tissue repair and remodelling. Unlike normal wound healing, during fibrosis active scaring does not cease once the initial insult is contained, with connective tissue formation and wound contraction persisting, leading to disrupted tissue formation. Mechanisms behind fibrosis are unknown but 
have been proposed to be due to excess TGF- $\beta 1$ and/or increased susceptibility of fibroblasts to persistent tissue re-modelling $(62,63) . T G F-\beta 1$ became an obvious target for genetic screening, with some evidence for a role in transplant loss found (see earlier). This opened the door for screening of other genes involved in fibrosis which may play a role in transplant survival.

Caveolin-1 (Cav-1) encodes part of caveolae, which form small invagination within the plasma membrane that act as specialized lipid rafts involved in signal transduction $(64,65)$. Caveolae play a role within numerous tissue remodelling and fibrotic pathways, including TGF- $\beta 1$ signalling and turn over, cell matrix interactions, fibroblast adhesion/migration, cell stretching and apoptosis (66). Decreased Cavl expression has been reported in affected tissues from several human fibrotic diseases including idiopathic pulmonary fibrosis, scleroderma and systemic sclerosis, with re-introduction of Cavl function shown to rescue these phenotypes $(66,67)$. Screening all common Cavl variation in two independent UK kidney transplant cohorts showed presence of Cav1 rs4730751 single nucleotide polymorphism (SNP) AA genotype in kidney donors was associated with increased risk of allograft failure, $H R=1.56-$ 1.97 (67). Importantly, the effect size of this variant is comparable with that of female donor gender and donor hypertension, both relevant clinical indicators of transplant success. Upon histological assessment of kidney graft failure, recipients who received grafts with the rs4730751 AA genotype had a predominant increase in interstitial fibrosis compared to donors with non-AA genotypes (67). Variation in Cavl has also been linked to decreased pancreas and lung transplant survival providing additional evidence for a role of fibrosis in long-term graft function (68-70). Interestingly, Cav1 knockout mice not only show impaired fibrosis but also exhibit lipid and metabolic disorders including insulin resistance $(64,71)$. Caveolin-1 is an essential scaffolding protein required for correct folding of the insulin receptor, with incorrect 
insulin receptor formation leading to insulin resistance $(64,72)$, suggesting Cav1 could contribute to reduced long-term graft function through other mechanisms in addition to fibrosis.

Whilst caveolin-1 is essential for caveolae formation, caveolin-2 is also involved in caveolae assembly in certain tissues (73). Screening common Cav2 variation in 575 kidney donors and recipients revealed association of two SNPs in the recipients with graft function however these effects did not remain associated upon multivariate analysis (74). Whilst no role for Cav2 was seen, screening other genes involved in caveolae formation/function could shed further light on the role of fibrosis in long-term graft function.

\section{Ethnic Differences in Transplant Outcome}

Analysis of 72,495 recipients of deceased and living donor kidneys undertaken in the USA between 2001-2005 showed both black and white recipients have decreased graft survival when transplanted with kidneys from black donors $(\mathrm{HR}=1.40$ and $\mathrm{HR}=1.35$, respectively, compared to white donor to white recipient) (75). Hispanic and Asian recipients showed no increased graft loss with kidneys from black donors $(\mathrm{HR}=0.87$ and $\mathrm{HR}=0.69$, respectively). Five year graft loss data showed white and black recipients have higher graft loss compared to Hispanic and Asian recipients, regardless of donor ethnicity (75). Differences in genetic variation across ethnic groups has been proposed to partly explain this difference in transplant survival.

In Apolipoprotein L1 (APOL1), which encodes a protein associated with plasma HDL cholesterol, two coding variants; a Serine to Glycine change at amino acid 342 (rs73885319) termed G1 and a six base pair deletion (rs71785313) termed G2, present in 30\% of AfricanAmericans and only $0.3 \%-0.1 \%$ of Europeans, are strongly associated with hypertension 
attributed end-stage renal disease in African-Americans $(76,77)$. When looking at 136 African Americans donor organ survival over 2 years, shorter graft survival rates were observed in recipients of donor kidneys with two $A P O L 1$ risk variants $(\mathrm{HR}=2.95, \mathrm{P}=0.01)$ and in a fully adjusted model, two $A P O L 1$ risk alleles independently predicted graft failure $(\mathrm{HR}=3.84$, $\mathrm{P}=0.008)$ (78). In African-Americans receiving deceased donors lacking two APOL1 risk variants, long-term survival rates were equivalent to those seen in non-African-American deceased kidney donor recipients in the US renal data systems between 1994-1998 (78).

APOL1 is expressed not only in the kidney but also in other organs including the liver, lung and placenta and is the only member of the apolipoprotein family that produces a soluble form (79). This has led to questions over whether $A P O L 1$ variants contribute to transplant outcome by causing increased APOL1 in the kidneys leading to nephrotoxicity or through the soluble form of APOL1 causing altered binding/reabsorption of HDL (as reviewed in (79)). Differences in APOL1 expression in normal kidneys compared to those from patients with HIV associated nephropathy (HIVAN) and focal segmental glomerulosclerosis (FSGS) has been found. In normal kidneys APOL1 expression was seen in podocytes, proximal tubules and arterial and arterior endothelial cells, whereas in HIVAN and FSGS APOL1 expression was reduced in the podocytes and tubules, with new expression seen in smooth muscles cells of the arterial walls (80). When looking at $A P O L 1$ genotype in African-American kidney transplant recipients (those who had two $A P O L 1$ variants compared to those with one or no APOL1 variants) no differences in graft survival was seen over 5 years of follow up, adding further support that it is donor kidney APOL1 expression, not soluble APOL1, that contributes to decreased graft survival (81). In vitro functional studies have also showed $A P O L 1$ risk variants cause podocyte swelling and reduced cellular viability at lower concentrations than wild-type APOL1 (82). Whilst further work is required to confirm these observations, this work suggests 
that identifying ethnic specific pathways will provide greater insights into graft survival in different ethnicities.

\section{Limitations of Candidate Gene Approach}

Whilst progress has been made in identifying genetic predictors of kidney transplant function, for every gene identified, numerous others genes investigated showed no association or inconclusive results $(3,7)$ Several challenges have faced candidate gene studies which may explain this including sample size, incomplete gene screening, cohort differences and lack of multivariate analysis (see Table 2).

Combined with these issues, investigating genes based purely on their potential or perceived function, could miss novel gene pathways that could be targeted therapeutically to improve transplant outcome. Employing non-bias genome screening techniques is one way of overcoming this. Recent advances in genetic screening methodology, including microarrays, Genome Wide Association Studies (GWAS) and next generation sequencing, combined with greater collaboration between centres enabling establishment of larger kidney transplant datasets, with greater statistical power, are enabling many of these problems to be overcome. With breakthroughs in these areas starting to emerge, the remainder of this review will focus on how these new advances are being utilised in transplantation.

\section{Genome Screening in Renal Transplant}

Non-bias monitoring of gene expression changes has been suggested as a way of identifying markers that could be used to predict graft rejection. Highly sensitive methods for quantifying 
gene transcripts, including real-time PCR, and large scale approaches such as microarrays have been employed to undertake transcriptional profiling of whole blood or graft biopsies. Whilst initially producing interesting results, microarray data in transplantation has suffered from lack of reproducibility across centres partially due to differences in cohort selection, treatment protocol and microarray technology (83). To address this, meta-analysis was undertaken on 8 independent microarray datasets, 236 samples, using graft loss data from four commonly transplanted organs (kidney, liver, heart and lung) obtained at time of biopsies to identify gene transcripts common to acute rejection across multiple graft types (84). Twelve gene transcripts, many of which were linked to $N F-K B$ and $S T A T 1$ signalling pathways, were overexpressed during acute rejection across all tissues, termed the common rejection model (CRM). Six of these genes target drugs that modulate immunosuppression or immune/inflammatory pathways. Validation in 794 renal allograft biopsies from three independent datasets, confirmed 11 of these genes transcripts were crucial to the CRM. Over time both progressors and nonprogressors to transplant loss showed increased CRM scores but progressors CRM scores increased more rapidly (84).

GWAS have also provided a new way of screening all common variation across the human genome (represented by $>500,000$ SNPs) for association with disease traits using high throughput chip genotyping technology. GWAS has revolutionised the search for genetic components to complex disease such as T1D and T2D, where within the space of a decade we have gone from a handful of known genes to $>50$ independent loci (85-88). Whilst GWAS has been undertaken in chronic kidney disease and other kidney traits, only limited GWAS in renal transplant have reported to date. O'Brien et al undertook GWAS to look at the role of recipient genotype on medium long-term kidney function measured by serum creatinine at five years post-transplant in 326 first time kidney transplant recipients. Regression analysis, incorporating 
clinical covariates, and principle component analysis identified one variant on chromosome 18 rs6565887 $\left(\mathrm{P}=4.05 \times 10^{-8}\right)$ that showed genome wide significance and another on chromosome 14 rs3811321 showing borderline genome wide significance $\left(\mathrm{P}=7.61 \times 10^{-8}\right)(89)$. Modelling rs 3811321 and rs656587 SNP effects explained $11.29 \%$ and $8.8 \%$ of five year creatinine variance, respectively, and together accounted for $17.4 \%$ of variance at this trait (89). Interestingly, rs3811321 and rs6565887 also correlated with allograft failure $(\mathrm{P}=0.004$ and $\mathrm{P}=0.03$, respectively). Both SNPs came up in regions not previously associated with kidney transplant function, with rs3811321 located within the T cell receptor alpha which forms part of the $\mathrm{T}$ cell receptor complex and rs6565887 present in a non-coding intron of zinc finger protein 516, a member of $\mathrm{C} 2 \mathrm{H} 2$-type zinc finger protein family located in nucleus cytoplasm, expressed in kidneys, spleen and lung (89). Whilst further work is required to confirm these associations, this highlights the strength of GWAS to identify new genes and disease pathways that will inevitably provide novel insights into transplant function as more GWAS are reported over the next few years.

\section{Insights from Related Diseases}

Sharing of susceptibility loci between related diseases is well established. This suggests that screening of GWAS hits from related kidney traits, such as chronic kidney function, and genes involved in survival of other transplanted organs, on customised genotyping chips for a role in renal transplant survival would show whether long-term kidney graft survival is driven by any general transplant loss or kidney disease specific pathways and whether the same variants are driving these effects across different diseases.

\section{Rare Variants}


Whilst rare variants and copy number variation $(\mathrm{CNVs})$ within the genome were originally believed to only contribute to monogenic forms of kidney disease, there is growing evidence that these variants may also impact upon complex disease. Advances in next generation sequencing technologies have enabled screening for rare variants and CNVs to become easier, with the genetic component to at least 160 different rare kidney diseases already identified (90). In the future, these technologies will enable us to determine if rare variants or CNVs also play a role in transplant outcome.

\section{Translating Genetic Signals into Disease Pathways}

One of the challenges this new influx of genetic data brings is how to determine the mechanisms driving these associations. Whilst association is assigned to a given gene, until fine mapping of the surrounding region, it is difficult to determine whether variation within that gene or a neighbouring gene region is truly driving the association detected. Even once fine mapping has been achieved, many of the variants driving association may be intronic or in gene deserts, requiring integration of information on gene expression, tissue specific expression, systems biology and animals models to determine how these variants impact upon transplant survival (91). Several initiatives have been set up to aid this process including the ENCODE project which has published extensive information on regions of transcription, transcription factor association, chromatin structure and histone modification in the human genome and the European Renal cDNA bank which is collecting gene expression data from renal biopsies enabling determination of gene expression in renal tissue (92-96). 
Some studies have already started to harness variation in gene expression for a role in transplant survival. Gene specific translational silencing by miRNAs regulates carcinogenic, immune and fibrotic pathways. A multicentre clinical trial investigated mRNA levels of CD3€ chain, perforin, granzyme B, proteinase inhibitor 9, CD103, interferon-inducible protein 10 (IP-10) within sequential urine specimens obtained at clinically stable points up to one year post transplant to determine if they predict acute rejection (97). Comparing mRNA in 43 urine samples from patients with acute rejection matched to urine samples from 163 patients showing no rejection (confirmed by BANFF biopsy grading) and 201 patients with stable graft function (no biopsy taken), showed that urinary cell levels of CD3, perforin, granzyme B and IP-10 normalised mRNA levels differed significantly amongst the three groups $(\mathrm{P}<0.001)$ (97). This enabled creation of a diagnosis signature using these three measures to distinguish biopsy samples showing acute rejection with $\mathrm{AUC}=0.85[95 \% \mathrm{CI}=0.78-0.91]$, with $79 \%$ sensitivity and $78 \%$ specificity $(\mathrm{P}<0.001)$. External validation in 71 complementary DNA samples, showed the three gene signature discriminated between acute cellular rejection and no rejection with $\mathrm{AUC}=0.74$, with $72 \%$ specificity and $71 \%$ sensitivity (97). This suggests understanding how gene variation affects gene transcription and silencing can be utilised in the transplant setting.

\section{Epigenetic Changes}

Temporal and reversible epigenetic alterations enable the body to silence or activate key genes in response to challenges encountered. Gene silencing via DNA methylation is one of the main epigenetic modifications within the body and whilst intrinsically difficult to monitor, some progress has been made accessing this. 
Differences in hypermethylated gene regions between primary human fibroblasts from fibrotic kidneys compared to non-fibrotic kidneys were assessed by genome wide methylation screening (98). Twelve genes including RASAL1, which has been associated with fibroblast activation and kidney fibrogenesis, were methylated in all 7 fibrotic fibroblast samples and non-methylated in all non-fibrotic fibroblasts, suggesting knockdown of these genes may be involved in onset of fibrosis (98). Random inactivation of one $\mathrm{X}$ chromosome in females is also undertaken via methylation to enable dosage compensation with males who only have one copy of the $\mathrm{X}$ chromosome. This leads to random inactivation of either the paternal or maternal $\mathrm{X}$ chromosome $(\mathrm{XCI})$, with females being a mosaic of the maternally and paternally derived $\mathrm{X}$ chromosome with an inactivation ratio of 50:50. In some cases one $\mathrm{X}$ chromosome is preferentially inactivated. A female with $>80 \%$ of one $\mathrm{X}$ chromosome inactivated are known as skewed, and those with $>90 \%$ of one $\mathrm{X}$ chromosome inactivated are known as extremely skewed. Investigating XCI levels in 212 white female recipients and 186 white donors, $8 \%$ of recipients with skewed XCI ( 2 of 25) developed biopsy proven acute rejection compared to $28.3 \%$ of non-skewed XCI recipients (53 of 187 ) $\mathrm{HR}=0.26, \mathrm{P}=0.02$ (99). In donors, $66.6 \%$ with XCI skewing (4 of 6) (66.6\%) developed acute rejection, compared with $20.5 \%$ of nonskewed donors without $\mathrm{XCI}$ skewing $\mathrm{HR}=3.30, \mathrm{P}=0.03$ (99). XCI skewing in recipients has been suggested to lead to immunological senescence within the recipient resulting in less rejection and in donors XCI skewing could lead to stem cell senescence resulting in reduced graft survival, explaining the protective and predisposing of XCI skewing respectively (99). Taken together these studies show that whilst tricky to access, understanding epigenetic modifications will provide insights into long-term transplant function.

\section{Relative Organ Age}


Older donor kidneys have faster progression to tubular atrophy and are more susceptibility to chronic graft dysfunction and failure (100-102). Kidney aging and decreased glomerular filtration rate becomes apparent after 40 years of age, however kidney function decline varies amongst individuals. Due to limited donor organ availability older organs are now being transplanted and, as such, markers that measure biological organ age could help optimize organ allocation. Telomeres, consisting of multiple copies of short nucleotide repeats at the end of all chromosomes, protect against chromosome deterioration. With each round of DNA replication, telomere length is reduced, which is believed to play a role in cell senescence and acts as a marker of organ 'age' $(103,104)$. In primates, ischemia-reperfusion was associated with rapid decrease in telomere length, suggesting that changes in relative organ age caused by transplantation could impact upon long-term outcome (105). To date, only limited studies have looked at telomere length and transplant outcome (106) to determine if relative graft 'age' impacts upon long-term function.

\section{Recipient-Donor Genetic Interactions}

With an increased number of genetic variants being associated with transplant survival and appreciation that both donor and recipient specific mechanisms could impact on graft outcome, one of the next challenges is to access how donor and recipient variants interact within a given individual and whether these pathways work synergistically or if one pathway plays a larger than others in long-term graft survival.

\section{Conclusion}


Advances in our ability to screen the genome, combined with greater understanding of how variants are linked to transplant outcome is providing new opportunities to learn more about the pathways behind graft survival and long-term function. The obvious next question is how do we use these new advances clinically to improve long-term transplant survival? Whilst it is important to bear in mind that clinical adaption of scientific discoveries is estimated to take up to 17 years $(107)$, there are some more immediate ways in which genetic variation can impact upon long-term graft survival. Improved understanding of the disease pathways involved in transplant survival and loss can provide an opportunity to identify early on those at greater risk of graft failure and/or inform the selection of more appropriate donor organs for transplantation. Some genetic variants, such as those within $C Y P 3 A 4$ and $C Y P 3 A 5$ which affect immunosuppressant metabolism, have more immediate potential to be translated into clinical practice and debate is already underway over whether initial drug dosing based on genotype should be implemented into immunosuppressant regimes $(35,39)$.

Decreased costs and increased reproducibility of whole genome sequencing is opening the doors to enable personalised medicine to become a reality and information on genetic variation that can affect long-term transplant outcome will be vital to tailoring therapeutic regimes and treatment options for transplant recipients $(108,109)$. In a time when drug design is becoming more expensive, the ability of genetics to identify new mechanisms involved in transplant loss could prove vital in identifying already approved drugs that could be re-purposed for use in transplant recipients to improve long-term graft function. Whilst it would be naive to say there are not challenges to face in both detecting genetic variation and translating the underlying mechanism $(108,109)$, ongoing advances in our understanding of the genetic variation behind transplant organ survival will undoubtedly continue to translate into improvements in patient 
care with the ultimate goal of making kidney transplantation a lifelong treatment for renal failure. 


\section{ACKNOWLEDGEMENTS}

I would like to thank the Diabetes Research and Wellness Foundation (DRWF) Non-Clinical Fellowship scheme for providing fellowship funding during the writing of this article. I would like to thank Dr Claire Onyimba for their helpful discussion and advice regarding the writing of this manuscript. 


\section{FIGURE \& TABLE LEGENDS}

Figure 1: Timeline of Different Genetic Techniques used to Identify Predictors of Renal Transplant Outcome

\section{Figure 2: Role of Calcineurin in T cell Activation}

Binding of the T cell receptor (TCR) to HLA class II molecules presenting non-self antigens triggers TCR activation. This leads to calcium signalling, which intern activates calcineurin. Calcineurin activation leads to dephosphorylation of its substrates, including nuclear factor of activated T-cells (NFAT) complexes, which translocate to the nucleus and alter gene expression. Inhibition of calcineurin and downstream NFAT proteins by calcineurin inhibitors is key to inhibiting $\mathrm{T}$ cell activation, enabling graft accommodation.

Table 1: Immune Response Genes Investigated for a Role in Predicting Transplant Survival and Long-Term Function

This table represents some of the most widely investigated immune response genes screened for a role in predicting transplant survival and long-term outcome. Conflicting results on their role in transplant outcome has made it difficult to determine if they play a role in transplant survival.

Table 2: Factors which Impacted Upon the Success of Candidate Gene Studies to Identify Predictors of Transplant Survival and Long-Term Function 


\section{REFERENCES}

1. Galichon P, Xu-Dubois YC, Finianos S, Hertig A, Rondeau E. Clinical and histological predictors of long-term kidney graft survival. Nephrology, dialysis, transplantation : official publication of the European Dialysis and Transplant Association - European Renal Association 2013; 28: 1362.

2. Massie AB, Kucirka LM, Segev DL. Big data in organ transplantation: registries and administrative claims. American journal of transplantation : official journal of the American Society of Transplantation and the American Society of Transplant Surgeons 2014; 14: 1723.

3. Goldfarb-Rumyantzev AS, Naiman N. Genetic prediction of renal transplant outcome. Current opinion in nephrology and hypertension 2008; 17: 573.

4. Lamb KE, Lodhi S, Meier-Kriesche HU. Long-term renal allograft survival in the United States: a critical reappraisal. American journal of transplantation : official journal of the American Society of Transplantation and the American Society of Transplant Surgeons 2011; 11: 450.

5. Travers ME, McCarthy MI. Type 2 diabetes and obesity: genomics and the clinic. Human genetics 2011; 130: 41.

6. Herder C, Roden M. Genetics of type 2 diabetes: pathophysiologic and clinical relevance. European journal of clinical investigation 2011; 41: 679.

7. Vaughan R, Sacks S. Genomics in human renal transplantation. Current opinion in immunology 2010; 22: 689.

8. Gough SC, Simmonds MJ. The HLA Region and Autoimmune Disease: Associations and Mechanisms of Action. Current genomics 2007; 8: 453.

9. Duquesnoy RJ, Marrari M. HLAMatchmaker-based definition of structural human leukocyte antigen epitopes detected by alloantibodies. Current opinion in organ transplantation 2009; 14: 403.

10. Duquesnoy RJ. Clinical usefulness of HLAMatchmaker in HLA epitope matching for organ transplantation. Current opinion in immunology 2008; 20: 594.

11. Duquesnoy RJ. Antibody-reactive epitope determination with HLAMatchmaker and its clinical applications. Tissue antigens 2011; 77: 525.

12. Duquesnoy RJ. HLAMatchmaker: a molecularly based algorithm for histocompatibility determination. I. Description of the algorithm. Human immunology 2002; 63: 339.

13. Duquesnoy RJ. A structurally based approach to determine HLA compatibility at the humoral immune level. Human immunology 2006; 67: 847.

14. Claas FH, Witvliet MD, Duquesnoy RJ, Persijn GG, Doxiadis, II. The acceptable mismatch program as a fast tool for highly sensitized patients awaiting a cadaveric kidney transplantation: short waiting time and excellent graft outcome. Transplantation 2004; 78: 190. 15. Papassavas AC, Stavropoulos-Giokas C, Boletis J, Ioannou S, Iniotaki-Theodoraki A, Kostakis A. Definition of permissible and immunogenic HLA antigens based on epitope analysis of the HLA specific antibodies produced in sensitized patients. European journal of immunogenetics : official journal of the British Society for Histocompatibility and Immunogenetics 2002; 29: 401.

16. Duquesnoy RJ, Witvliet M, Doxiadis, II, de Fijter H, Claas FH. HLAMatchmakerbased strategy to identify acceptable HLA class I mismatches for highly sensitized kidney transplant candidates. Transplant international : official journal of the European Society for Organ Transplantation 2004; 17: 22.

17. Claas FH, Dankers MK, Oudshoorn M, van Rood JJ, Mulder A, Roelen DL, et al. Differential immunogenicity of HLA mismatches in clinical transplantation. Transplant immunology 2005; 14: 187. 
18. Doxiadis, II, Duquesnoy RJ, Claas FH. Extending options for highly sensitized patients to receive a suitable kidney graft. Current opinion in immunology 2005; 17: 536.

19. Duquesnoy RJ, Howe J, Takemoto S. HLAmatchmaker: a molecularly based algorithm for histocompatibility determination. IV. An alternative strategy to increase the number of compatible donors for highly sensitized patients. Transplantation 2003; 75: 889.

20. Laux G, Mytilineos J, Opelz G. Critical evaluation of the amino acid triplet-epitope matching concept in cadaver kidney transplantation. Transplantation 2004; 77: 902.

21. Kosmoliaptsis V, Sharples LD, Chaudhry A, Johnson RJ, Fuggle SV, Halsall DJ, et al. HLA class I amino acid sequence-based matching after interlocus subtraction and long-term outcome after deceased donor kidney transplantation. Human immunology 2010; 71: 851.

22. Crabtree GR, Olson EN. NFAT signaling: choreographing the social lives of cells. Cell 2002; 109 Suppl: S67.

23. Graef IA, Chen F, Chen L, Kuo A, Crabtree GR. Signals transduced by $\mathrm{Ca}(2+)$ /calcineurin and NFATc3/c4 pattern the developing vasculature. Cell 2001; 105: 863.

24. Neilson JR, Winslow MM, Hur EM, Crabtree GR. Calcineurin B1 is essential for positive but not negative selection during thymocyte development. Immunity 2004; 20: 255.

25. Staatz CE, Tett SE. Clinical pharmacokinetics and pharmacodynamics of tacrolimus in solid organ transplantation. Clinical pharmacokinetics 2004; 43: 623.

26. van Hooff JP, Boots JM, van Duijnhoven EM, Christiaans MH. Dosing and management guidelines for tacrolimus in renal transplant patients. Transplantation proceedings 1999; 31: 54S.

27. van Gelder T, van Schaik RH, Hesselink DA. Practicability of pharmacogenetics in transplantation medicine. Clinical pharmacology and therapeutics 2014; 95: 262.

28. Pham PT, Schaenman J, Pham PC. BK virus infection following kidney transplantation: an overview of risk factors, screening strategies, and therapeutic interventions. Current opinion in organ transplantation 2014; 19: 401.

29. Evans WE, McLeod HL. Pharmacogenomics--drug disposition, drug targets, and side effects. The New England journal of medicine 2003; 348: 538.

30. Staatz CE, Goodman LK, Tett SE. Effect of CYP3A and ABCB1 single nucleotide polymorphisms on the pharmacokinetics and pharmacodynamics of calcineurin inhibitors: Part II. Clinical pharmacokinetics 2010; 49: 207.

31. Staatz CE, Goodman LK, Tett SE. Effect of CYP3A and ABCB1 single nucleotide polymorphisms on the pharmacokinetics and pharmacodynamics of calcineurin inhibitors: Part I. Clinical pharmacokinetics 2010; 49: 141.

32. Christians U, Kohlhaw K, Budniak J, Bleck JS, Schottmann R, Schlitt HJ, et al. Ciclosporin metabolite pattern in blood and urine of liver graft recipients. I. Association of ciclosporin metabolites with nephrotoxicity. European journal of clinical pharmacology 1991; 41: 285 .

33. Lemoine A, Azoulay D, Gries JM, Dennison A, Castaing D, Fredj G, et al. Relationship between graft cytochrome P-450 3A content and early morbidity after liver transplantation. Transplantation 1993; 56: 1410.

34. MacPhee IA, Fredericks S, Tai T, Syrris P, Carter ND, Johnston A, et al. The influence of pharmacogenetics on the time to achieve target tacrolimus concentrations after kidney transplantation. American journal of transplantation : official journal of the American Society of Transplantation and the American Society of Transplant Surgeons 2004; 4: 914.

35. Thervet E, Loriot MA, Barbier S, Buchler M, Ficheux M, Choukroun G, et al. Optimization of initial tacrolimus dose using pharmacogenetic testing. Clinical pharmacology and therapeutics 2010; 87: 721. 
36. Wang D, Guo Y, Wrighton SA, Cooke GE, Sadee W. Intronic polymorphism in CYP3A4 affects hepatic expression and response to statin drugs. The pharmacogenomics journal 2011; 11: 274.

37. Elens L, Bouamar R, Hesselink DA, Haufroid V, van der Heiden IP, van Gelder T, et al. A new functional CYP3A4 intron 6 polymorphism significantly affects tacrolimus pharmacokinetics in kidney transplant recipients. Clinical chemistry 2011; 57: 1574.

38. Elens L, Capron A, van Schaik RH, De Meyer M, De Pauw L, Eddour DC, et al. Impact of CYP3A4*22 allele on tacrolimus pharmacokinetics in early period after renal transplantation: toward updated genotype-based dosage guidelines. Therapeutic drug monitoring 2013; 35: 608.

39. Pallet N, Jannot AS, El Bahri M, Etienne I, Buchler M, de Ligny BH, et al. Kidney Transplant Recipients Carrying the CYP3A4*22 Allelic Variant Have Reduced Tacrolimus Clearance and Often Reach Supratherapeutic Tacrolimus Concentrations. American journal of transplantation : official journal of the American Society of Transplantation and the American Society of Transplant Surgeons 2015.

40. Moore J, McKnight AJ, Dohler B, Simmonds MJ, Courtney AE, Brand OJ, et al. Donor $\mathrm{ABCB} 1$ variant associates with increased risk for kidney allograft failure. Journal of the American Society of Nephrology : JASN 2012; 23: 1891.

41. Ghisdal L, Van Laecke S, Abramowicz MJ, Vanholder R, Abramowicz D. New-onset diabetes after renal transplantation: risk assessment and management. Diabetes care 2012; 35: 181.

42. Heit JJ, Apelqvist AA, Gu X, Winslow MM, Neilson JR, Crabtree GR, et al. Calcineurin/NFAT signalling regulates pancreatic beta-cell growth and function. Nature 2006; 443: 345.

43. Heit JJ. Calcineurin/NFAT signaling in the beta-cell: From diabetes to new therapeutics. BioEssays : news and reviews in molecular, cellular and developmental biology 2007; 29: 1011.

44. Laperrousaz S, Tiercy S, Villard J, Ferrari-Lacraz S. HLA and non-HLA polymorphisms in renal transplantation. Swiss medical weekly 2012; 142: w13668.

45. Radaev S, Sun PD. Structure and function of natural killer cell surface receptors. Annual review of biophysics and biomolecular structure 2003; 32: 93.

46. Deng L, Mariuzza RA. Structural basis for recognition of MHC and MHC-like ligands by natural killer cell receptors. Seminars in immunology 2006; 18: 159.

47. Bashirova AA, Martin MP, McVicar DW, Carrington M. The killer immunoglobulinlike receptor gene cluster: tuning the genome for defense. Annual review of genomics and human genetics 2006; 7: 277.

48. Kunert K, Seiler M, Mashreghi MF, Klippert K, Schonemann C, Neumann K, et al. KIR/HLA ligand incompatibility in kidney transplantation. Transplantation 2007; 84: 1527.

49. Chen $\mathrm{G}$, Chen S, Chen X. Role of complement and perspectives for intervention in transplantation. Immunobiology 2013; 218: 817.

50. Koscielska-Kasprzak K, Bartoszek D, Myszka M, Zabinska M, Klinger M. The complement cascade and renal disease. Archivum immunologiae et therapiae experimentalis 2014; 62: 47.

51. Cohen D, Colvin RB, Daha MR, Drachenberg CB, Haas M, Nickeleit V, et al. Pros and cons for C4d as a biomarker. Kidney international 2012; 81: 628.

52. Racusen LC, Colvin RB, Solez K, Mihatsch MJ, Halloran PF, Campbell PM, et al. Antibody-mediated rejection criteria - an addition to the Banff 97 classification of renal allograft rejection. American journal of transplantation : official journal of the American Society of Transplantation and the American Society of Transplant Surgeons 2003; 3: 708. 
53. Brown KM, Kondeatis E, Vaughan RW, Kon SP, Farmer CK, Taylor JD, et al. Influence of donor $\mathrm{C} 3$ allotype on late renal-transplantation outcome. The New England journal of medicine 2006; 354: 2014.

54. Simmonds MJ, Gough SC. Endocrine Autoimunity. Oxford Textbook of Endocrinology \& Diabetes; 2010.

55. Han FF, Fan H, Wang ZH, Li GR, Lv YL, Gong LL, et al. Association between costimulatory molecule gene polymorphism and acute rejection of allograft. Transplant immunology 2014; 31: 81.

56. Kloda K, Domanski L, Bobrek-Lesiakowska K, Pawlik A, Safranow K, Kwiatkowska E, et al. The impact of CTLA4 and PTPN22 genes polymorphisms on long-term renal allograft function and transplant outcomes. Renal failure 2013; 35: 1223.

57. Thakkinstian A, Dmitrienko S, Gerbase-Delima M, McDaniel DO, Inigo P, Chow KM, et al. Association between cytokine gene polymorphisms and outcomes in renal transplantation: a meta-analysis of individual patient data. Nephrology, dialysis, transplantation : official publication of the European Dialysis and Transplant Association European Renal Association 2008; 23: 3017.

58. Buckham TA, McKnight AJ, Benevente D, Courtney AE, Patterson CC, Simmonds M, et al. Evaluation of five interleukin genes for association with end-stage renal disease in white Europeans. American journal of nephrology 2010; 32: 103.

59. Letterio JJ, Roberts AB. Regulation of immune responses by TGF-beta. Annual review of immunology 1998; 16: 137.

60. Mantel PY, Schmidt-Weber CB. Transforming growth factor-beta: recent advances on its role in immune tolerance. Methods in molecular biology 2011; 677: 303.

61. Sandholm N, Salem RM, McKnight AJ, Brennan EP, Forsblom C, Isakova T, et al. New susceptibility loci associated with kidney disease in type 1 diabetes. PLoS genetics 2012; 8: e1002921.

62. Serini G, Gabbiana G. Modulation of alpha-smooth muscle actin expression in fibroblasts by transforming growth factor-beta isoforms: an in vivo and in vitro study. Wound repair and regeneration : official publication of the Wound Healing Society [and] the European Tissue Repair Society 1996; 4: 278.

63. Vaughan MB, Howard EW, Tomasek JJ. Transforming growth factor-beta1 promotes the morphological and functional differentiation of the myofibroblast. Experimental cell research 2000; 257: 180.

64. Schwencke C, Braun-Dullaeus RC, Wunderlich C, Strasser RH. Caveolae and caveolin in transmembrane signaling: Implications for human disease. Cardiovascular research 2006; 70: 42 .

65. Ohno-Iwashita Y, Shimada Y, Hayashi M, Inomata M. Plasma membrane microdomains in aging and disease. Geriatrics \& gerontology international 2010; 10 Suppl 1: S41.

66. Gvaramia D, Blaauboer ME, Hanemaaijer R, Everts V. Role of caveolin-1 in fibrotic diseases. Matrix biology : journal of the International Society for Matrix Biology 2013; 32: 307.

67. Moore J, McKnight AJ, Simmonds MJ, Courtney AE, Hanvesakul R, Brand OJ, et al. Association of caveolin-1 gene polymorphism with kidney transplant fibrosis and allograft failure. JAMA : the journal of the American Medical Association 2010; 303: 1282.

68. Vandermeulen E, Ruttens D, Verleden SE, Vos R, Van Raemdonck DE, Kastelijn EA, et al. Genetic variation in caveolin-1 affects survival after lung transplantation. Transplantation 2014; 98: 354.

69. Kastelijn EA, van Moorsel CH, Kazemier KM, Roothaan SM, Ruven HJ, Kwakkel-van Erp JM, et al. A genetic polymorphism in the CAV1 gene associates with the development of 
bronchiolitis obliterans syndrome after lung transplantation. Fibrogenesis \& tissue repair 2011; 4: 24.

70. Hamilton A, Mittal S, Barnardo MC, Fuggle SV, Friend P, Gough SC, et al. Genetic Variation in Caveolin-1 Correlates With Long-Term Pancreas Transplant Outcome. American Journal of Transplantation 2015; In Press.

71. Le Lay S, Kurzchalia TV. Getting rid of caveolins: phenotypes of caveolin-deficient animals. Biochimica et biophysica acta 2005; 1746: 322.

72. Chidlow JH, Jr., Sessa WC. Caveolae, caveolins, and cavins: complex control of cellular signalling and inflammation. Cardiovascular research 2010; 86: 219.

73. Sowa G. Caveolae, caveolins, cavins, and endothelial cell function: new insights. Frontiers in physiology 2012; 2: 120.

74. McCaughan JA, Duffy S, O'Hagan T, Courtney AE, Borrows R, Conlon PJ, et al. Comprehensive investigation of the caveolin 2 gene: resequencing and association for kidney transplant outcomes. PloS one 2013; 8: e63358.

75. Callender CO, Cherikh WS, Traverso P, Hernandez A, Oyetunji T, Chang D. Effect of donor ethnicity on kidney survival in different recipient pairs: an analysis of the OPTN/UNOS database. Transplantation proceedings 2009; 41: 4125.

76. Genovese G, Friedman DJ, Ross MD, Lecordier L, Uzureau P, Freedman BI, et al. Association of trypanolytic ApoL1 variants with kidney disease in African Americans. Science 2010; 329: 841.

77. Tzur S, Rosset S, Shemer R, Yudkovsky G, Selig S, Tarekegn A, et al. Missense mutations in the APOL1 gene are highly associated with end stage kidney disease risk previously attributed to the MYH9 gene. Human genetics 2010; 128: 345.

78. Reeves-Daniel AM, DePalma JA, Bleyer AJ, Rocco MV, Murea M, Adams PL, et al. The APOL1 gene and allograft survival after kidney transplantation. American journal of transplantation : official journal of the American Society of Transplantation and the American Society of Transplant Surgeons 2011; 11: 1025.

79. Kruzel-Davila E, Wasser WG, Aviram S, Skorecki K. APOL1 nephropathy: from gene to mechanisms of kidney injury. Nephrology, dialysis, transplantation : official publication of the European Dialysis and Transplant Association - European Renal Association 2015.

80. Madhavan SM, O'Toole JF, Konieczkowski M, Ganesan S, Bruggeman LA, Sedor JR. APOL1 localization in normal kidney and nondiabetic kidney disease. Journal of the American Society of Nephrology : JASN 2011; 22: 2119.

81. Lee BT, Kumar V, Williams TA, Abdi R, Bernhardy A, Dyer C, et al. The APOL1 genotype of African American kidney transplant recipients does not impact 5-year allograft survival. American journal of transplantation : official journal of the American Society of Transplantation and the American Society of Transplant Surgeons 2012; 12: 1924.

82. Lan X, Jhaveri A, Cheng K, Wen H, Saleem MA, Mathieson PW, et al. APOL1 risk variants enhance podocyte necrosis through compromising lysosomal membrane permeability. American journal of physiology Renal physiology 2014; 307: F326.

83. Lakkis FG, Billiar TR. Molecular analysis of transplant rejection: marching onward. The Journal of experimental medicine 2013; 210: 2147.

84. Khatri P, Roedder S, Kimura N, De Vusser K, Morgan AA, Gong Y, et al. A common rejection module (CRM) for acute rejection across multiple organs identifies novel therapeutics for organ transplantation. The Journal of experimental medicine 2013; 210: 2205.

85. Bradfield JP, Qu HQ, Wang K, Zhang H, Sleiman PM, Kim CE, et al. A genome-wide meta-analysis of six type 1 diabetes cohorts identifies multiple associated loci. PLoS genetics 2011; 7: e1002293. 
86. Barrett JC, Clayton DG, Concannon P, Akolkar B, Cooper JD, Erlich HA, et al. Genome-wide association study and meta-analysis find that over 40 loci affect risk of type 1 diabetes. Nature genetics 2009; 41: 703.

87. Morris AP, Voight BF, Teslovich TM, Ferreira T, Segre AV, Steinthorsdottir V, et al. Large-scale association analysis provides insights into the genetic architecture and pathophysiology of type 2 diabetes. Nature genetics 2012; 44: 981.

88. Replication DIG, Meta-analysis C, Asian Genetic Epidemiology Network Type 2 Diabetes C, South Asian Type 2 Diabetes C, Mexican American Type 2 Diabetes C, Type 2 Diabetes Genetic Exploration by Nex-generation sequencing in muylti-Ethnic Samples C, et al. Genome-wide trans-ancestry meta-analysis provides insight into the genetic architecture of type 2 diabetes susceptibility. Nature genetics 2014; 46: 234.

89. O'Brien RP, Phelan PJ, Conroy J, O'Kelly P, Green A, Keogan M, et al. A genomewide association study of recipient genotype and medium-term kidney allograft function. Clinical transplantation 2013; 27: 379.

90. Devuyst O, Knoers NV, Remuzzi G, Schaefer F, Board of the Working Group for Inherited Kidney Diseases of the European Renal A, European D, et al. Rare inherited kidney diseases: challenges, opportunities, and perspectives. Lancet 2014; 383: 1844.

91. Witasp A, Ekstrom TJ, Schalling M, Lindholm B, Stenvinkel P, Nordfors L. How can genetics and epigenetics help the nephrologist improve the diagnosis and treatment of chronic kidney disease patients? Nephrology, dialysis, transplantation : official publication of the European Dialysis and Transplant Association - European Renal Association 2014; 29: 972.

92. Cohen CD, Frach K, Schlondorff D, Kretzler M. Quantitative gene expression analysis in renal biopsies: a novel protocol for a high-throughput multicenter application. Kidney international 2002; 61: 133.

93. Lindenmeyer MT, Eichinger F, Sen K, Anders HJ, Edenhofer I, Mattinzoli D, et al. Systematic analysis of a novel human renal glomerulus-enriched gene expression dataset. PloS one 2010; 5: e11545.

94. Yasuda Y, Cohen CD, Henger A, Kretzler M, European Renal c DNABC. Gene expression profiling analysis in nephrology: towards molecular definition of renal disease. Clinical and experimental nephrology 2006; 10: 91.

95. Consortium EP. The ENCODE (ENCyclopedia Of DNA Elements) Project. Science 2004; 306: 636.

96. Kellis M, Wold B, Snyder MP, Bernstein BE, Kundaje A, Marinov GK, et al. Defining functional DNA elements in the human genome. Proceedings of the National Academy of Sciences of the United States of America 2014; 111: 6131.

97. Suthanthiran M, Schwartz JE, Ding R, Abecassis M, Dadhania D, Samstein B, et al. Urinary-cell mRNA profile and acute cellular rejection in kidney allografts. The New England journal of medicine 2013; 369: 20.

98. Bechtel W, McGoohan S, Zeisberg EM, Muller GA, Kalbacher H, Salant DJ, et al. Methylation determines fibroblast activation and fibrogenesis in the kidney. Nature medicine 2010; 16: 544.

99. Simmonds MJ, Benavente D, Brand OJ, Moore J, Ball S, Ferro CJ, et al. Skewing of female X-chromosome inactivation: an epigenetic risk factor for kidney transplantation outcome. Transplantation 2013; 95: e25.

100. Zhou XJ, Rakheja D, Yu X, Saxena R, Vaziri ND, Silva FG. The aging kidney. Kidney international 2008; 74: 710.

101. Lim WH, Clayton P, Wong G, Campbell SB, Cohney S, Russ GR, et al. Outcomes of kidney transplantation from older living donors. Transplantation 2013; 95: 106.

102. Melk A, Schmidt BM, Braun H, Vongwiwatana A, Urmson J, Zhu LF, et al. Effects of donor age and cell senescence on kidney allograft survival. American journal of 
transplantation : official journal of the American Society of Transplantation and the American Society of Transplant Surgeons 2009; 9: 114.

103. Hayflick L, Moorhead PS. The serial cultivation of human diploid cell strains. Experimental cell research 1961; 25: 585.

104. Sanders JL, Newman AB. Telomere Length in Epidemiology: A Biomarker of Aging, Age-Related Disease, Both, or Neither? Epidemiologic reviews 2013.

105. Chkhotua AB, Schelzig H, Wiegand P, Grosse S, Reis S, Art M, et al. Influence of ischaemia/reperfusion and LFA-1 inhibition on telomere lengths and CDKI genes in ex vivo haemoperfusion of primate kidneys. Transplant international : official journal of the European Society for Organ Transplantation 2005; 17: 692.

106. Oetting WS, Guan W, Schladt DP, Wildebush WA, Becker J, Thyagarajan B, et al. Telomere length of recipients and living kidney donors and chronic graft dysfunction in kidney transplants. Transplantation 2014; 97: 325.

107. Crossing the Quality Chasm: A New Health System for the 21st Century. Washington (DC); 2001.

108. Manolio TA. Bringing genome-wide association findings into clinical use. Nature reviews Genetics 2013; 14: 549.

109. Palotie A, Widen E, Ripatti S. From genetic discovery to future personalized health research. New biotechnology 2013; 30: 291. 


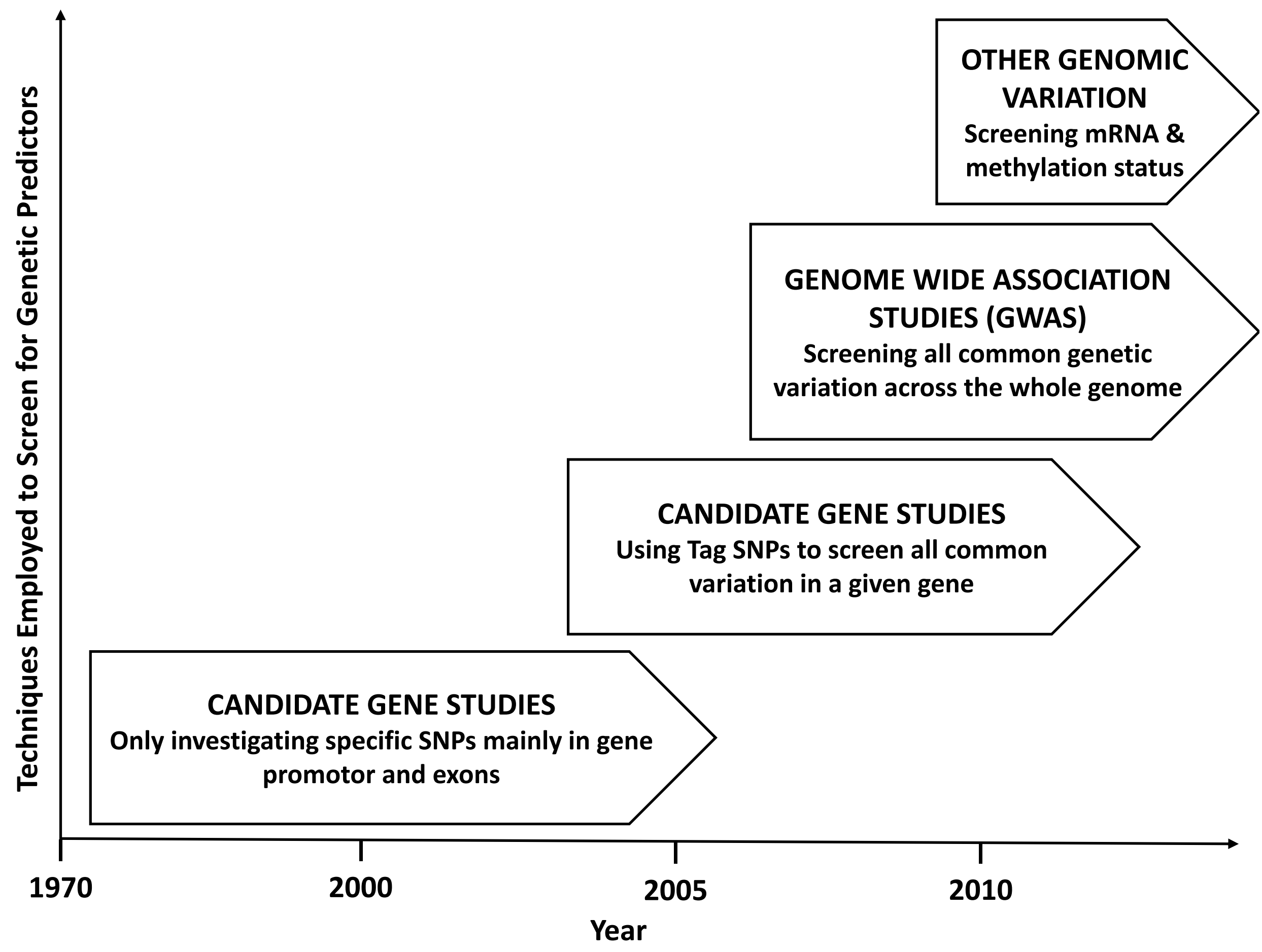


Figure 1: Timeline of Different Genetic Techniques used to Identify Predictors of Renal Transplant Outcome 


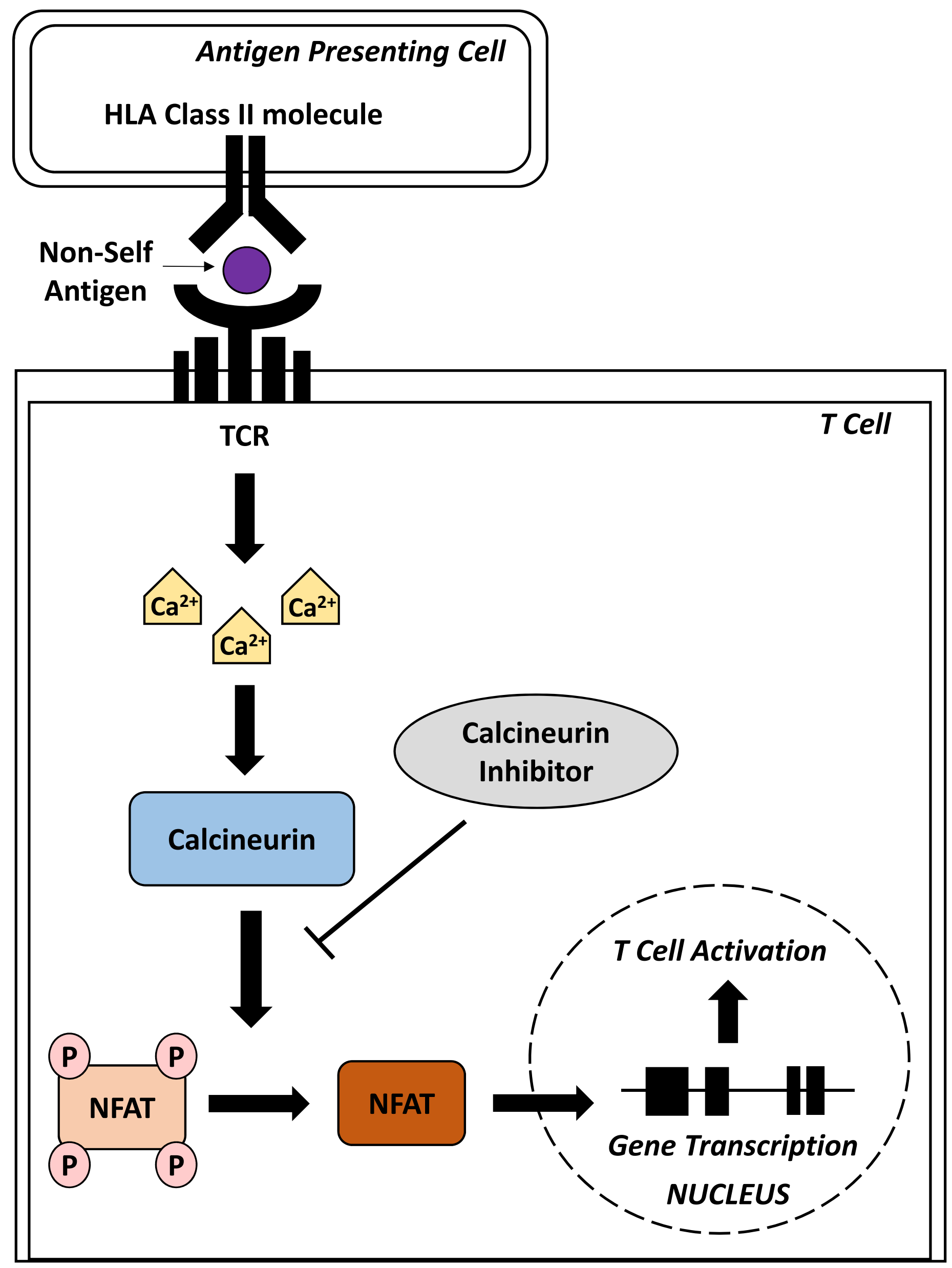




\section{Figure 2: Role of Calcineurin in $\mathbf{T}$ cell Activation}

Binding of the T cell receptor (TCR) to HLA class II molecules presenting nonself antigens triggers TCR activation. This leads to calcium signalling, which intern activates calcineurin. Calcineurin activation leads to dephosphorylation of its substrates, including nuclear factor of activated T-cells (NFAT) complexes, which translocate to the nucleus and alter gene expression. Inhibition of calcineurin and downstream NFAT proteins by calcineurin inhibitors is key to inhibiting $\mathrm{T}$ cell activation, enabling graft accommodation. 


\begin{tabular}{|c|c|c|}
\hline Gene & Function & Role in Immune System \\
\hline ICAM-1 & $\begin{array}{l}\text { Adhesion } \\
\text { molecule }\end{array}$ & $\begin{array}{l}\text { Is an intracellular adhesion molecule and is involved in } \\
\text { facilitating antigen presentation to T cells and mediating cell } \\
\text { trafficking to sites of tissue injury. }\end{array}$ \\
\hline$M C P-1$ & Chemokine & $\begin{array}{l}\text { Involved in recruiting immune cells to sight of inflammation } \\
\text { triggered by tissue injury or infection. }\end{array}$ \\
\hline$C C R 2$ & Chemokine & $\begin{array}{l}\text { Encodes the receptor of MCP-1 and is involved in } \\
\text { inflammation. }\end{array}$ \\
\hline CCR5 & Chemokine & $\begin{array}{l}\text { Functions as a chemokine receptor for RANTES and MIP } \\
\text { and is proposed to play a role in the inflammatory response } \\
\text { triggered after infection. }\end{array}$ \\
\hline$I L-1$ & Cytokine & $\begin{array}{l}\text { Leads to activation of pro-inflammatory cytokines and is } \\
\text { involved in regulating inflammation. }\end{array}$ \\
\hline$I L-2$ & Cytokine & $\begin{array}{l}\text { Involved in regulating the body's response to infection and in } \\
\text { discriminating between self and non-self antigens within the } \\
\text { body. }\end{array}$ \\
\hline$I L-6$ & Cytokine & $\begin{array}{l}\text { Secreted by T cells and macrophages and is involved in } \\
\text { controlling inflammation through both pro-inflammatory and } \\
\text { anti-inflammatory functions. }\end{array}$ \\
\hline$I L-10$ & Cytokine & $\begin{array}{l}\text { An anti-inflammatory cytokine involved in immune } \\
\text { regulation. }\end{array}$ \\
\hline$T N F-a$ & Cytokine & $\begin{array}{l}\text { Plays a role in controlling inflammation through regulation } \\
\text { of immune cell function. }\end{array}$ \\
\hline$T G F-\beta 1$ & $\begin{array}{l}\text { Growth } \\
\text { factor }\end{array}$ & $\begin{array}{l}\text { Produced by numerous immune cells and plays a role in } \\
\text { regulating the inflammatory response. }\end{array}$ \\
\hline$H M O X 1$ & $\begin{array}{l}\text { Anti- } \\
\text { inflammatory } \\
\text { molecule }\end{array}$ & $\begin{array}{l}\text { Is upregulated in response to numerous noxious stimuli and } \\
\text { is part of cytoprotective mechanisms crucial for defence of } \\
\text { cells and tissues against internal stressors. }\end{array}$ \\
\hline
\end{tabular}


Table 1: Immune Response Genes Investigated for a Role in Predicting Transplant Survival and Long-Term Function

This table represents some of the most widely investigated immune response genes screened for a role in predicting transplant survival and long-term outcome. Conflicting results on their role in transplant outcome has made it difficult to determine if they play a role in transplant survival. 


\begin{tabular}{|c|c|}
\hline Factor & $\begin{array}{l}\text { How this impacted upon the ability of candidate gene studies to } \\
\text { identify genetic predictors of transplant outcome }\end{array}$ \\
\hline Sample size & $\begin{array}{l}\text { Transplant outcome is likely governed by numerous genetic effects with } \\
\text { small HRs on transplant outcome. Sample sizes of }<1000 \text { recipients and } \\
\text { donors, restricts the power these studies have to detect smaller HRs. This } \\
\text { could particularly impact upon replication of new findings which might } \\
\text { be overinflated initially due to 'winner curse' and then not be picked up in } \\
\text { similarly sized replication datasets which are underpowered to detect the } \\
\text { true smaller HR. }\end{array}$ \\
\hline $\begin{array}{l}\text { Incomplete } \\
\text { gene } \\
\text { screening }\end{array}$ & $\begin{array}{l}\text { Many studies only screened selected variants within the gene promoter } \\
\text { and exons. Greater understanding of the importance of intronic and other } \\
\text { non-coding genomic variation on gene expression, suggests that } \\
\text { incomplete screening of genes could lead to associations being missed. }\end{array}$ \\
\hline $\begin{array}{l}\text { Cohort } \\
\text { differences }\end{array}$ & $\begin{array}{l}\text { Recipient and donor selection criteria, immunosuppressant regime and } \\
\text { ethnic differences could impact upon genetic associations. }\end{array}$ \\
\hline $\begin{array}{l}\text { Multivariate } \\
\text { analysis }\end{array}$ & $\begin{array}{l}\text { Variation in clinical features known to influence transplant outcome need } \\
\text { to be adjusted for to ensure they are not impacting upon genetic } \\
\text { associations. }\end{array}$ \\
\hline $\begin{array}{l}\text { Recipient only } \\
\text { analysis }\end{array}$ & $\begin{array}{l}\text { Genetic associations may be present in both donor and recipients } \\
\text { genomes. Since appreciation of this within the mid-2000s this issue has } \\
\text { been somewhat addressed with more studies looking at genetic predictors } \\
\text { in both kidney donors and kidney transplant recipients genomes where } \\
\text { DNA is available to undertake such analysis. }\end{array}$ \\
\hline
\end{tabular}


Table 2: Factors which Impact Upon the Success of Candidate Gene Studies to Identify Predictors of Transplant Survival and Long-Term Function 